Ткалич А. И.

ПЕРВЫЙ КАМЧАТСКИЙ МИССИОНЕРСКИЙ СЪЕЗД И ЕГО ИСТОРИКО-КУЛЬТУРНОЕ ЗНАЧЕНИЕ ДЛЯ КАМЧАТКИ

В НАЧАЛЕ ХХ ВЕКА

Ткалич А. И.

A. I. Tkalich

ПЕРВЫЙ КАМЧАТСКИЙ МИССИОНЕРСКИЙ СЬЕЗД И ЕГО

ИСТОРИКО-КУЛЬТУРНОЕ ЗНАЧЕНИЕ ДЛЯ КАМЧАТКИ

В НАЧАЛЕ ХХ века

\title{
THE FIRST KAMCHATKA MISSIONARY CONGRESS AND ITS HISTORICAL AND CULTURAL IMPORTANCE FOR THE KAMCHATKA PENINSULA IN THE BEGINNING OF THE $20^{\text {th }}$ CENTURY
}

Ткалич Алексей Иванович - кандидат педагогических наук, доцент Православного Свято-Тихоновского гуманитарного университета (Россия, Москва); 115184, г. Москва, ул. Иловайская, 19/1, каб. 502; 8(915) 243-89-97. E-mail: tkalichai@mail.ru.

Mr. Aleksey I. Tkalich - PhD in Pedagogy, Assistant Professor, St. Tikhon's Orthodox Humanities University. (Russia, Moscow); 115184, Moscow, Ilovayskaja str., 19/1, of. 502; 8(915)243-89-97. E-mail: tkalichai@mail.ru.

Аннотация. Развитию социально-культурной и духовно-просветительской деятельности русской православной церкви на Камчатке в начале XX века уделено не так много внимания наших отечественных и зарубежных исследователей. При этом Первый Камчатский миссионерский съезд 1914 года до сих пор остается своеобразным белым пятном. Несколько дореволюционных и советских авторов, так или иначе, упоминают этот съезд, но эти упоминания носят больше информационный, нежели исследовательский, характер. Вопросы, которые поднимались на этом съезде, призваны были заострить внимание общественности на проблемах дальнейшего развития православия на территории Крайнего Северо-Востока.

Summary. Not as much attention as wished was paid by Russian and foreign researchers to the issue of development of the social, cultural and religious education of Russian Orthodox Church on Kamchatka at the beginning of the XX century. The First Kamchatka missionary congress, which happened in February, 1914, is still a white spot. Several pre-revolutionary and Soviet authors mention it, anyhow, but these references are not exploratory, they are informative. Contemporaries should have felt the results of implementation of decisions made during the conference. The aim of the issues, raised at the First Kamchatka's missionary congress, was to sharpen public attention to the problems of further development of Orthodoxy on the territory of the Utmost North-East.

Ключевые слова: Крайний Северо-Восток, православие, Первый Камчатский миссионерский съезд, коренные этносы Камчатки.

Key words: Extreme Northeast, orthodoxy, the first Kamchatka's missionary congress, indigenous people of Kamchatka.

УДК 008:1-027.21

Развитию социально-культурной и духовно-просветительской деятельности русской православной церкви на Камчатке в начале XX в. уделено не так много, как хотелось бы, внимания наших отечественных и зарубежных исследователей. При этом такое яркое событие, как Первый Камчатский миссионерский съезд, состоявшийся в феврале 1913 г., до сих пор остается загадкой. Несколько авторов, так или иначе, упоминают этот съезд: Г. Ф. Севильгаев в своей монографии, посвященной истории просвещения малых народов Дальнего Востока» (1972), И. С. Вдовин в книге «Ламаизм и христианство» (1979), приводя свои аргументы, касающиеся влияния христианства на религиозные верования чукчей и коряков; Нестор Анисимов в книге «Моя Камчатка», в монографии «Православная миссия» в отдельной главе дается описание и оценка съезду, объективно повлиявшему на жизнь коренных народов Крайнего Северо-Востока (2011). Насколько актуально изучать Камчатский православный миссионерский съезд с современной точки зрения, какие уроки 


\section{Ученые записки

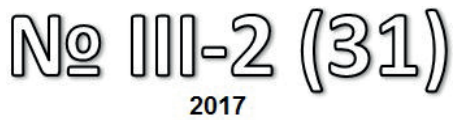

можно извлечь из его решений, или он может быть интересен только как исторический факт, попробуем разобраться.

Как показывает анализ протоколов съезда, опубликованных в нескольких номерах Владивостокских епархиальных ведомостей за 1914 г., вопросы, которые поднимались на Первом Камчатском миссионерском съезде, призваны были заострить внимание общественности на весьма важные проблемы дальнейшего становления и развития Православия на территории Крайнего Северо-Востока - на Камчатке и Чукотке, побережье Охотского моря и в Гижиге. Сам съезд предварялся большой организационной и подготовительной работой. Все будущие делегаты заранее, в письменном виде выдвинули вопросы для коллективного обсуждения.

Съезд был собран в селении Иоасафовском, на севере Камчатки. Открытие состоялось 18 февраля 1913 г. Известие о начале съезда облетело все селения и стойбища Камчатки. Миссионеры съезжались за сотни и тысячи верст. Многие из них подвергались в пути серьезной смертельной опасности, попадали в пургу, преодолевали коварные наледи и глубокие ущелья. Немало прибыло на съезд и представителей коренного населения - для Камчатки это было огромное и важное событие. Круг вопросов, который должен был рассмотреть съезд, касался повседневной жизни и деятельности камчатских миссионеров: о необходимости более частого посещения стойбищ постоянно кочующих «инородцев»; внушении благоговейного отношения к крестильным крестикам и иконам; о разъяснении крещеным значения христианского имени, которое они носят, и о точном определении возраста «инородцев»; школах для детей крещеных оленеводов и о возможном типе этих школ, программе, составе учащихся; переводах на языки коренного населения Камчатки богослужебных книг и о богослужениях на этих языках и проповедях; занятиях в школах при начальном обучении «инородцев» на их родном наречии; чтении Часов в часовнях, где нет священников, о миссионерских и школьных библиотеках и многом другом, жизненно важном и необходимом для успешной деятельности миссионеров Крайнего Северо-Востока.

Многие проблемы требовали тщательной проработки и обращения к общероссийскому церковному опыту, например: как поститься кочевым жителям региона, если в их рационе нет или почти нет растительной пищи. Другой вопрос: как готовиться к исповеди в условиях скученности населения в ярангах и условиях постоянных перекочевок. Еще один немаловажный вопрос: можно ли священнику брать в дорогу оружие, ведь в пути на многие версты его подстерегает опасность от дикого зверя. Немедленного решения вопроса требовала статистика оседлых и кочующих жителей Камчатского полуострова - каждый год в исповедных росписях приходилось отмечать одних и тех же людей в разных приходах, так как кочующие жители стойбищ постоянно кочевали с места на место в поисках лучших кормов для своих оленей. Многие крещеные коряки не знали своих лет и имен, данных при крещении, называя и то, и другое наугад. В связи с этим все участники съезда высказали пожелание как можно скорее устроить народную перепись в Камчатской области с привлечением священников-миссионеров.

О разъяснении крещеным «инородцам» их христианского имени слушали доклад священника Паланского Свято-Никольского прихода, о. Николая Лонгинова. После обмена мнениями решили, во-первых, внушать всем крещеным, чтобы они называли друг друга не по-язычески, а православным именем, и, во-вторых, для точности записи заносить в метрики в скобках и языческие имена, чтобы не происходило ошибок.

С пониманием и сочувствием заслушали депутаты и участники съезда доклад начальника Камчатской миссии о. Нестора о том, что миссионерам часто приходится служить в холодных и дымных юртах и подземных жилищах, куда приходится спускаться по закопченному и скользкому столбу со Святыми Дарами и крестом. Не лучше обстоит дело и со службой в продуваемых насквозь и холодных камчатских церквях и часовнях, в которых Святые Дары приходится отогревать своим дыханием. Но если где появляется возможность, устраивать часовни и молитвенные помещения, даже если это будут всего лишь полуземлянки, обложенные дерном или снегом. Хорошо также, если на месте совершаемых богослужений будет сооружен крест в память о событии. Немаловажным был вопрос о строительстве на территории Камчатской области новых церквей и часовен. По докладу священников и псаломщиков Лесновского, Дранкинского и Паланского при- 
Ткалич А. И.

ПЕРВЫЙ КАМЧАТСКИЙ МИССИОНЕРСКИЙ СЪЕЗД И ЕГО ИСТОРИКО-КУЛЬТУРНОЕ ЗНАЧЕНИЕ ДЛЯ КАМЧАТКИ В НАЧАЛЕ ХХ ВЕКА

ходов решили строить новые, более просторные храмы и школы при них, особенно там, где имелся строевой лес; в селениях Подкагирное и Рекинники, при отсутствии строевого леса, устроить часовни в виде землянок. Начальник миссии, о. Нестор высказался о необходимости перестройки школы и дома для священника в с. Кичиги, а также возведении часовен в селениях Алюторском, Ветвейском, Вывенском, Каменском и на Таватомских горячих ключах. Анадырский (Марковский) священник, о. Агафопод Шипицын, просил решить вопрос об устройстве часовен в урочище Алгане, на устье р. Белой, перестроить из нового имеющегося леса часовню в Ерополе. Необходимо, по его мнению, было также построить церковь-школу в устье р. Анадырь, в Ново-Мариинском посту, а также на м. Чукотский Нос.

Кроме вопросов церковного строительства, участников съезда волновал также вопрос о школах для кочевников-оленеводов. Необходимо было обсудить и договориться о возможном типе такой школы и составе учащихся. Проблема главным образом состояла в том, что дети оленеводов с самых ранних лет участвуют в общем процессе труда наравне со взрослыми: мальчики пасут и охраняют оленей день и ночь, посменно, а девочки делят со своими матерями заботу по ведению домашнего хозяйства: шьют или ремонтируют одежду и обувь, выделывают массу шкур, готовят еду, собирают дрова, плетут неводы и сети, заготавливают рыбу и разделывают оленя. Разобрав все «за» и «против», делегаты и участники съезда признали обучение детей оленеводовкоряков «желательным, насколько то представится возможным». Количество церковноприходских школ для жителей Камчатской области необходимо, как решили делегаты съезда, по возможности увеличивать. Эти школы должны были стать доступными для всех - и для крещеных, и для некрещеных, и для детей, и для взрослых. Пример тому - школа в селении Иоасафовском, куда вслед за детьми приходили и взрослые. Во всех школах необходимо было ввести, хотя бы в общедоступных рамках, обучение медицине, а также ремесленные занятия, среди которых столярное ремесло, слесарное, токарное, кузнечное, переплетное, сапожное, портняжное. Для девочек и женщин - это рукоделие и шитье. Необходимо было также в миссионерских школах ввести изучение собаководства и оленеводства с основами ветеринарии. Словом, подвел черту под своим выступлением о. Нестор, для Камчатской области необходимо выработать на практике особый тип миссионерской церковно-просветительской ремесленной школы.

О переводах на языки коренных жителей Камчатской области богослужебных и других книг, о проповедях и беседах на этих языках и богослужении в национальных селениях, о занятиях в школах, особенно при первоначальном обучении на родном наречии «инородцев» было выслушано выступление начальника Миссии о. Нестора. Он затронул весьма важную проблему - как добиться того, чтобы коренное население стало христианами не только наружно, но и внутренне. Для этого очень важно, чтобы миссионер знал язык народа, среди которого ему приходится работать. Еще апостол Павел писал в своем «Послании к коринфянам»: «Если приду к вам братия и стану говорить на незнакомых языках, то какую принесу вам пользу? Если вы произносите невразумительные слова, то как узнают, что вы говорите? Вы будете говорить на ветер». В церкви, продолжал Апостол, - я хочу лучше пять слов сказать умом моим, чтобы и других наставить, нежели тьму слов на непонятном языке (Кор. 14,6-9). Исходя из всего этого, миссионер должен обязательно изучать языки коренного населения Камчатской области. Необходимо, чтобы богослужение для не знающих русского языка коряков и тунгусов-эвенов совершалось на их родном наречии; первое время хотя бы частями, или попеременно, то на русском, то на «инородческом». А проповедь обязательно произносить только на родном для слушателей языке. Только тогда высокие христианские истины дойдут до сердец жителей Камчатской области. Неоспоримый пример тому - как действовал великий миссионер и Апостол Японии - архиепископ Николай, чья паства возросла за короткое время до 35 тысяч человек. Мало того, когда богослужение проводилось на незнакомом, для тех же коряков, русско-славянском языке, они, не понимая сути происходящего, ходили, сидели, лежали, смеялись и громко переговаривались, приводили в молитвенное помещение собак и не отгоняли их от священника и походного престола. Все это ими делалось безотчетно, по непониманию. Молитва православного священника была для них то же, что и шаманское заклинание, только в иной форме. 
Говоря о переводах богослужебных книг и молитв на языки коренного населения Камчатской области, о. Нестор затронул и такую проблему, как установление церковного пения на «инородческих» языках. Необходимо было приложить все силы, чтобы в Камчатских церквях стало реальностью православное пение, совершаемое на понятном прихожанам языке. Этим можно было бы привлечь внимание не только уже крещеных, к богослужению, но даже и некрещеных, потому что благоговейное православное пение сильно проникает в душу, увеличивая во сто крат впечатление от службы церковной. Пример такому благотворному влиянию - богослужение на корякском языке, которое о. Нестор совершал в церкви с. Иоасафовское уже с 1911 г. Участники и члены съезда, выслушав сообщение о. Нестора, постановили продолжать переводческую деятельность на своих приходах, а также признали полезным первоначальное обучение учащихся вести на национальных языках коренных жителей Камчатской области. Решили также собрать все привезенные миссионерами тексты проповедей, молитвы и словари, внимательно просмотреть и проверить, а затем издать. Для просмотра и проверки создали специальную комиссию из участников съезда.

Доклад священника-миссионера из Паланы о. Николая Лонгинова касался вопроса, можно ли допускать учителей или почтенных грамотных мужчин читать Часы и утреннее богослужение в часовнях в воскресные и праздничные дни, там, где нет священника. Обсудив этот вопрос, постановили, что ради удовлетворения хотя бы элементарной духовной потребности, а также для того чтобы народ в праздники не предавался разгулу и лени, допускать указанных лиц читать и петь Часы, тропари и молитвы, положенные по уставу православной церкви в воскресные и праздничные дни в часовнях, где нет священника. На одном из заседаний священник-миссионер о. Карп Головач высказался о пользе чтений и вне богослужебных бесед в школах, - для учащихся и всего вообще населения, а также о желательности введения таких бесед как обязательных и по возможности с последним техническим достижением - «волшебным фонарем». Это предложение было принято. Участники съезда согласились с мнением священника из Дранки о. Карпа и просили о. Нестора как Начальника Духовной Камчатский миссии ходатайствовать перед Преосвященным о приобретении для пяти миссионерских станов - Иоасафовского, Дранкинского, Лесновского, Паланского и Анадырского-Марковского - так называемых «волшебных фонарей».

Доклад о. Нестора о борьбе с пьянством и употреблением мухоморов был встречен с большим вниманием, поскольку вопрос о борьбе с этим злом в Камчатской области и, в частности, среди коренного населения весьма актуален: Инородец и камчадал до болезненности падок на всякие спиртные напитки. Он готов отдать последнюю одежду, всю (добытую) пушнину, все свое добро и богатство за стакан или бутылку водки или спирта. Но достать-то спиртные напитки в изолированном крае нелегко и не всегда можно. Но если уж довелось достать, то он их старается выпить один, или с приятелями все сразу, будь то бесчисленное множество вина. Долг миссионеров, - продолжал докладчик, - спасать нашу паству: инородцев, болеющих и беднеющих от алкоголя. Вопрос борьбы со спаиванием камчадалов и инородцев весьма сложный, над которым надо серьезно поработать. Прежде всего, миссионеры должны быть сами хорошим наглядным примером трезвой жизни и внушать в проповедях и беседах о вреде алкоголя. Они должны приводить инородцам наглядные и яркие примеры гибели людей от алкоголя. Но еще ужаснее, - продолжал свое выступление о. Нестор, - когда инородцы-коряки едят ядовитые грибы-мухоморы. Мухомор быстро и сильно действует опьяняюще и отравляюще на весь организм человека. Получаются необыкновенные судороги, корчи, изо рта идет пена, является галлюцинация, помогающая дикарям веровать в злого духа, якобы во время действия мухомора, беседующего с ними $[3,33]$.

Одно из заседаний съезда было посвящено борьбе с жестокими языческими обрядами и обычаями и, в частности, принесении в жертву собак. Убивали, как правило, самых лучших ездовых собак-передовиков, цена которым - от 50 до 150 рублей и выше. Все это проделывалось по повелению шамана, которому якобы передал так сделать злой дух. У корякских острожков на Парени выставлены были целые ряды убитых собак. Миссионерам рекомендовалось объяснять корякам, что им как христианам не подобает следовать языческим обрядам и обычаям. Убивать собак недопустимо как с гуманной точки зрения, так и с материальной, ведь они в суровой северной жизни - незаменимые помощники людей. 
Ткалич А. И.

ПЕРВЫЙ КАМЧАТСКИЙ МИССИОНЕРСКИЙ СЪЕЗД И ЕГО ИСТОРИКО-КУЛЬТУРНОЕ ЗНАЧЕНИЕ ДЛЯ КАМЧАТКИ

В НАЧАЛЕ ХХ ВЕКА

Вопрос о многоженстве и незаконном сожительстве среди коренного населения Камчатской области был поднят также начальником Миссии о. Нестором. Он обратил внимание участников съезда на незаконные браки и ненормальную женитьбу в селениях, среди камчадалов и коряков. Виной тому были сохранившиеся языческие обычаи. Родители жениха и невесты после взаимного соглашения допускали их к супружеской жизни еще до совершеннолетия и до совершения таинства законного брака. Еще абсолютно неразвитые в половом отношении дети, по сути, калечили свое здоровье. Девочки от этого умирали при преждевременных родах или на всю жизнь оставались больными. Был приведен пример о том, что вымерли все девочки-подростки в селении Дранка и во многих других, корякских и камчадальских селениях. Многие мальчики, подростки, на вопрос, венчались ли они, отвечали: «Нет, я только женат». Здесь была необходима настойчивая и усиленная забота о прекращении ненормальных женитьб, сожительств и калечении здоровья детей [6, 147].

Следующий вопрос, выдвинутый начальником Камчатской миссии, касался крестных ходов и значении их в духовном воспитании инородческой паствы. Главное занятие оседлого населения области - рыболовство. Для народов Камчатской области рыба заменяет хлеб. При плохом улове, который случался чуть ли не через год, население голодало. Полезно поэтому перед каждым началом рыбной ловли совершать крестный ход с освящением неводов, рек и моря. Рыбная ловля благословенный труд самим Господом и Святыми Апостолами - рыболовами. Так как в требнике имелась только молитва на благословение мрежей (неводов), о. Нестор предложил участникам съезда составить ходатайство Преосвященному Евсевию о разрешении на написание молитвы на освящении и благословение рыбной ловли. Он обосновал свое предложение тем, что в Святом Евангелии можно немало почерпнуть поучительного о рыбной ловле, применяя в то же время рыбную ловлю к молитве душ человеческих для вечного спасения. Коренной житель должен смотреть на рыбную ловлю как на труд, благословенный самим Богом. Участники съезда согласились с предложением о. Нестора и постановили перед началом рыбной ловли совершать крестный ход на освящение рек, моря и благословение мрежей (неводов). Вопрос о составлении молитвы на благословение и освящение начала рыбной ловли решено было предоставить через начальника Миссии, архиепископу Владивостокскому Евсевию.

Не менее важным и нужным участники и члены съезда посчитали доклад о. Нестора о необходимости бережного и внимательного отношения к церковным и миссионерским архивам. Известно, что старинные архивы при Камчатских церквях не сохранились, будучи расхищены, заброшены и уничтожены временем, а большей частью - людьми. В связи с этим о. Нестор предложил всем членам съезда приложить все свое старание к сохранению церковных архивов.

Делегаты съезда согласились также с необходимостью постоянно записывать особенности верований и обрядов язычников, их жизнь, быт, обычаи, суеверия, приметы, сказки, рассказы, песни, пословицы и басни и другое, сохраняя все это при церковных архивах.

Следующий вопрос - об устройстве обители милосердия на горячих целебных Паратунских источниках близ Петропавловска и основании мужского миссионерского монастыря в долине реки Камчатки. Волновал участников и членов съезда и вопрос о поднятии авторитета церковнодуховной власти в Камчатской области. В связи с тем, что самостоятельная административная власть на Камчатке, как и судебная, уже пять лет была установлена и действовала, посчитали ускорить появление здесь самостоятельной епископской кафедры, так как в самый разгар церковного строительства крайне недоставало духовного руководителя высокого звания. Обсудив этот вопрос, участники съезда постановили, что для пользы духовного возрождения и процветания Камчатской области в православно-русском духе необходимо ускорить поднятие авторитета духовной власти на Камчатке.

Таким образом, Камчатский миссионерский съезд поднял на своих заседаниях достаточно обширный перечень вопросов организационного и духовно-нравственного содержания. В качестве предстоящих задач миссионерской работы среди коренного населения Камчатской области дал в своем докладе начальник Миссии, о. Нестор: «...Надеть туземцу крест при крещении и думать, что уже сделано все нужное, и на том успокоиться, - этого мы, миссионеры, не должны допускать... нужно принять ...меры к устранению препятствий в посещении отдаленных стойбищ и острож- 


\section{Ученые записки \\ Комсомольского-на-Амуре государственного технического университета

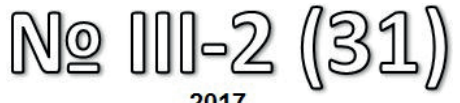 \\ 2017}

ков... и установить более тесную, близкую, постоянную связь между крещеными и священникоммиссионером. Это последнее можно достигнуть только путем широкого церковно-школьного строительства в Камчатской миссии. Как можно больше в доступных местах и районах оседлой и кочевой жизни... нужно (иметь) церквей, часовен, школ, молитвенных домов, миссионерских станов и походных миссий». Нужно также, «...чтобы русское имя было любимо на Камчатке. Здесь миссионерам предстоит положить немало труда. Нужен живой, наглядный пример нравственной, трезвой, трудолюбивой жизни камчатского пастыря и учителя, являющегося в Камчатскую область для просвещения и обрусения края» $[2,144]$.

После завершения съезда, с 21 по 23 февраля в селении Иоасафовском совершались крестные ходы. Местное население и гости, коренные жители Камчатки впервые увидели такое количество священнослужителей Православной Церкви вместе. Блеск облачений, стройное, правильное пение, торжественность богослужений - все это произвело неизгладимое впечатление на всех присутствующих. Однако самое главное и важное - это то, что Первый Камчатский миссионерский съезд наметил конкретные задачи и способы их решения. Миссионерское движение на Камчатке получило перспективу своего дальнейшего развития и роста. Съезд не только собрал всех миссионеров воедино, но и образовал из них мощный поток, устремившийся к единой цели.

\section{ЛИТЕРАТУРА}

1. Летопись Православного Камчатского Братства // Владивостокские епархиальные ведомости. - 1914. № $3,4,7-12,16,18$.

2. Нестор (Анисимов), митр. Мои воспоминания. - М., 1995.

3. Нестор (Анисимов), иеромонах. Записки Камчатского миссионера // Православный Благовестник. 1909. - № 1 .

4. Отчет Православного Камчатского Братства за 1913-1914 отчетный год // Владивостокские епархиальные ведомости. - 1915. - № 2.

5. Севильгаев, Г. Ф. Очерки по истории просвещения малых народов Дальнего Востока / Г. Ф. Севильгаев. Л., 1972. - С. 45.

6. Ткалич, А. И. Православная миссия на Крайнем Северо-Востоке / А. И. Ткалич. - М.: МГОУ, 2011. - 235 с. 